\title{
BREXIT, ARTICLE 50 AND THE CONTESTED BRITISH CONSTITUTION*
}

\begin{abstract}
Art 50 TEU process, and those aspects that relate most clearly to British constitutional law. Its overarching theme is that the Brexit process is rendered highly problematic by the lack of any coherent conception of the British Constitution. Different parties settle on interpretations of constitutional law that support their case, but often there is no determinative answer. Three broad issues are examined in order to substantiate this claim: the EU Referendum, the triggering of Article 50, and the Devolution aspect of Brexit. I argue that each of these issues reveals tensions and competing constitutional interpretations that suggest that the British Constitution is ill-equipped to deal with Brexit.
\end{abstract}

\section{INTRODUCTION}

On 23 June 2016, the UK overall voted to leave the European Union, by a majority of $51.9 \%$ to $48.1 \% .{ }^{1}$ In order to leave the EU, however, the UK will have to follow the process set out in Art 50 TEU. This article discusses the early stages of the Art 50 process, and those aspects that relate most clearly to British constitutional law. Its overarching theme is that the Brexit process is rendered highly problematic by the lack of any coherent conception of the British Constitution. Different parties settle on interpretations of constitutional law that support their case, but often there is no determinative answer.

This point may be illustrated with the example of sovereignty. There has been much talk of sovereignty in the Referendum context, with certain parties employing a mantra of 'Take back control', but there has been less clarity as to what sovereignty actually means. However, at its most basic, there are at least three notions of sovereignty that are relevant in the context of Brexit, and they are often confused. The first is parliamentary sovereignty, which is said to have particular resonance in the UK because, due to the vagaries of the uncodified UK Constitution, the Westminster Parliament has been recognised as a body with unlimited legislative power. Yet the parliamentary sovereignty of a representative democracy may seem to be at odds with popular sovereignty as exercised in a referendum. Popular sovereignty also has other implications, such as in Scotland, where an indigenous Scottish tradition claims that sovereignty resides in the Scottish people, in spite of the alternative claims of Diceyan parliamentary sovereignty. Thirdly, there is external sovereignty: whereby a country may be sovereign and recognised as independent by the international community. But states recognise that international agreements such as NATO, or EU treaties, curb sovereignty in practice. However, these constraints are willingly accepted by states because of the benefits that pooling or ceding some sovereignty can bring - indeed it can even enhance sovereignty in another sense of a state's power or ability to deal with certain issues.

These are three different concepts of sovereignty, but they have become very confused in the context of Brexit and the UK's relations with the EU. Part of the problem is that not only are these conceptions at war with each other, but that they are also sometimes internally incoherent. ${ }^{2}$ Sovereignty claims are also bound up in three broader issues that are discussed in

\footnotetext{
* This article is to be published in the Modern Law Review in 2016. I would like to thank the editor and an anonymous reviewer for comments and suggestions. In thinking about the issues in this article I have learned much from discussions with Professor Sir David Edward, Professor Michael Keating and Dr Kirsty Hughes, although they might not agree with everything I write here, and any errors are of course completely my own.

${ }^{1}$ See the Electoral Commission, UK Referendum results: http://www.electoralcommission.org.uk/find-informationby-subject/elections-and-referendums/past-elections-and-referendums/eu-referendum/electorate-and-countinformation

${ }^{2}$ For example, as Tomkins and Turpin note, the label 'parliamentary sovereignty' is misleading. 'What the doctrine establishes...is the legal supremacy of statute, which is not quite the same thing as the sovereignty of Parliament'.
} 
this article: the Referendum, the triggering of Article 50, and the Devolution aspect of Brexit. I argue that each of these issues reveals tensions and competing constitutional interpretations that suggest that the British Constitution is ill-equipped to deal with Brexit.

\section{THE EU REFERENDUM ACT 2015 AND THE ROLE OF REFERENDUMS IN UK LAW}

First, some reflections about the Referendum itself. After all, Art 50 would not be at issue if the Referendum had not been held, and produced a particular result.

The EU Referendum was a creature of the EU Referendum Act 2015. There is no requirement in the Act that the UK Government implement its results, nor does the statute set any time limit for implementing a vote to leave the EU. It was an advisory rather than a mandatory referendum, enabling the electorate to express its opinion before any legislation might be introduced. ${ }^{3}$

The EU Referendum vote is an expression of popular sovereignty. But referendums have not been a highly significant feature of UK Constitutional law and there is still uncertainty as to their place in our Constitution, ${ }^{4}$ and how they accord with a constitutional tradition based on parliamentary sovereignty. UK-wide referendums were not used until the later $20^{\text {th }}$ century, and notably, many important issues such as declaring war, decolonization, abolition of capital punishment, legalization of homosexuality, the welfare state, royal abdications, measures limiting powers of the Crown and House of Lords, were not subject to referendums. UK constitutional law (Scotland may be a different matter) does not acknowledge a principle of popular sovereignty. Instead, sovereignty is seen as resting with the Crown in Parliament, and UK politics is based on representative democracy. ${ }^{5}$ Although there may be democratic arguments for referendums, their use might appear to undermine parliamentary sovereignty, if the popular vote goes against the preferences of the majority of MPs (as was apparently the case in June's EU Referendum ${ }^{6}$ ).

Since the 1970s, however, referendums have become more common in the UK, most notably perhaps, in the case of devolution to Scotland, Wales and Northern Ireland, and membership of the EU. However, their use has not always been due to a desire for direct democracy. Rather, in some cases they have been used instrumentally by governments. In 2010, the House of Lords Constitution Committee, in its report on referendums in the UK, declared that 'we regret the ad hoc manner in which referendums have been used, often as a tactical device, by the government of the day. ${ }^{77}$ Referendums have been held to overcome government divisions, as in 1975, when Harold Wilson held a referendum over EEC membership to deal with divisions in the Labour party, or as a concession to hostile backbenchers, as in the Devolution referendums of 1979. The $2011 \mathrm{AV}$ referendum sprung from promises and deals made within

A. Tomkins and C. Turpin, British Government and the Constitution: Text and Materials (Cambridge University Press, 2011) 59.

${ }^{3}$ This is in contrast to eg the AV referendum, instigated by the Parliamentary Voting System and Constituencies Act 2011, s. 8 of which provided that alternative vote provisions would come into force if there were a majority of 'Yes' votes cast in the referendum. In the event, there was a No vote and so this did not happen.

${ }^{4}$ However, it should be noted that plebiscites were reasonably frequent in the British colonial context, and also associated with the process of decolonization.

${ }^{5}$ England did not develop a tradition of popular sovereignty in constitutional terms, even if there were sometimes talk of a 'sovereignty of the electorate' in political terms. However, such a sovereignty of the electorate only allowed the electorate to choose the government, it did not ground the British Constitution in the authority of the people, and Parliament could alter political rights. This is unlike the case of written constitutions, such as the US Federal Constitution, whose legitimacy is explicitly stated to be based on the authority of 'We the people'.

6 See eg 'EU vote: Where the Cabinet and other MPs stand,' BBC News, 22 June 2016, at http://www.bbc.co.uk/news/uk-politics-eu-referendum-35616946

${ }^{7}$ House of Lords, Select Committee on the Constitution, 12th Report of Session 2009-10 'Referendums in the United Kingdom' at para 62. 
Coalition government. The 2016 EU Referendum was a response to fractious dissent within the Conservative party, and also a reaction to external pressure posed by Ukip.

Implementing the EU referendum vote will institute major constitutional change in the UK. Because of its uncodified constitution, the UK lacks specific mechanisms for constitutional amendment, in contrast to many other jurisdictions that make special provision for it. The US federal Constitution is well known for making constitutional amendment extremely hard to achieve. In many jurisdictions worldwide, specific constitutional constraints are set on referendum use, such as voting thresholds, requirements for supermajorities, protection of devolved regions, and so on, in order that constitutions not be subject to tactical political purposes. Bruce Ackerman has suggested that major constitutional issues should be put to the voters twice before enacted into law, and that this would help the thoughtfulness of voters' decisions. ${ }^{8}$ At time of writing, there have been calls for a further referendum on the terms of any Withdrawal Agreement negotiated by the UK with the EU. Ackerman also warned of the dangers of referendum systems: 'a poorly designed system could serve as a platform for pandering to the worst instincts of the public, as countless demagogues have shown since Napoleon first demonstrated the abusive potential of referendums in the aftermath of the French Revolution. ${ }^{9}$ Indeed, in the UK, referendums have sometimes instituted forms of special majority, such as a specified level of support in terms of votes, or a specific turnout, as was the case in the Devolution referendums of $1979^{10}$ (which failed to achieve these requirements). However, the EU Referendum Act contained no such provisions. It is important that its follow-up should not be instrumental and unprincipled.

\section{The consequences of the $\mathrm{EU}$ referendum}

The EU Referendum result has been momentous, not just in terms of the UK's relationship with the EU, but also for our understanding of the British Constitution. It is frankly astonishing that there could be so little clarity about such matters as whether an Act of Parliament is necessary to trigger Article 50 TEU, whether there should be another referendum to approve any Withdrawal Agreement, and whether the devolved nations should have any considerable role in all of this. Can the British Constitution really be fit for purpose if there can be so little certainty over these matters?

It has already been stated that the referendum is advisory only. Legally, both the government and Parliament could choose to ignore it. They could choose never to trigger Art 50 TEU, never repeal the European Communities Act (ECA) 1972, nor ever take any other step inimical to the UK's EU membership. That would be both lawful and constitutional. According to classic, Diceyan notions of sovereignty, if Parliament is actually sovereign it can legislate to do anything, including to ignore a non-binding referendum.

So whether a referendum is legally binding depends on the structure of the legislation which enables it. Parliament decides that. The UK does not have a codified constitution with provisions requiring referendum results to be implemented, unlike, for example, Ireland, where the circumstances in which a binding referendum is held are set out in its Article 47 of its Constitution.

However, it has become a truism to add that politically the situation is quite different, and that it would be highly inexpedient to ignore the referendum result. Yet there are many examples where governments have believed it politically possible to do just that. So, for

\footnotetext{
${ }^{8}$ B. Ackerman, 'At the Crossroads', London Review of Books, 9 September 2010, 32-33.

${ }^{9}$ Ibid, at 32 .

10 'The 1979 Referendums' available at:

http://www.bbc.co.uk/news/special/politics97/devolution/scotland/briefing/79referendums.shtml.
} 
example, in July 2015 the Greek people voted by a roughly $20 \%$ majority to reject austerity conditions that would be imposed by EU and other international institutions in return for a large bailout. Notwithstanding, the Greek government agreed soon after to perhaps even tougher measures. ${ }^{11}$ In 2008, Irish voters rejected the Lisbon Treaty, but in 2009 a second referendum was held in Ireland, with $67 \%$ of voters instead now backing the treaty. ${ }^{12} \mathrm{EU}$ treaties aside, we may turn to Sweden, which in 1955 held a referendum concerning which side of the road cars should drive on. Although $83 \%$ Swedes voted to remain driving on the left, the government ignored this vote and later legislated to introduce driving on the right, believing this to be in the interests of the Swedish people. ${ }^{13}$ So even politics need not dictate action on referendum results.

Yet the government does not seem minded to ignore the referendum result and stated in the policy paper, 'The Process for Withdrawing from the European Union', published in February 2016, that it is under a 'democratic duty to give effect to the electorate's decision." ${ }^{14}$ This view was presented to Parliament and was not challenged.

What then is required by way of follow up. We have heard that 'Brexit means Brexit' - but what does this mean? What, as a matter of law, does a vote to leave the EU in the referendum require?

Neither the referendum legislation, nor the vote itself, provide any mandate or guidance as to what the UK's future relationship may be with the EU, or with other states (which will not be dealt with in any detail in the Art 50 negotiations). The question put to the electorate was in binary form: 'Should the United Kingdom remain a member of the European Union or leave the European Union?' 15 The electorate voted only to leave the EU. They did not agree to any particular exit agreement. ${ }^{16}$ Some of those who voted Leave may desire a Norwegian style arrangement, which would mean EEA membership involving access to the Single Market, and associated freedom of movement. For other Leave voters, however, terminating freedom of movement for EU citizens is the reason why they voted to Leave. However, these issues were not put to the electorate in the Referendum and were not in any electoral manifesto. For example, the Conservative party, in its May 2015 general election manifesto, made no commitments as to the UK's future relationship with the EU in the event of a No vote in any EU referendum. So the government (even less so, given the change of Prime Minister and most other members of the Cabinet) has no electoral mandate for any specific policy on future relations with EU.

A key argument of Brexiteers has been the need to restore powers and sovereignty to Parliament, but referendums may sometimes be at odds with parliamentary sovereignty, which is usually held to be based on representative government principles of the sort here described by Burke:

\footnotetext{
11 'Greek debt crisis: What was the point of the referendum?' BBC News, 11 July 2015, at http://www.bbc.co.uk/news/world-europe-33492387.

12 'Ireland votes in favour of Lisbon Treaty', The Observer, 4 October 2009 at https://www.theguardian.com/world/2009/oct/04/ireland-votes-yes-lisbon-treaty.

13 'Dagen H: The day Sweden switched sides of the road', The Washington Post, 17 February 2012 at https://www.washingtonpost.com/blogs/blogpost/post/dagen-h-the-day-sweden-switched-sides-of-the-roadphoto/2012/02/17/gIQAOwFVKR_blog.html.

14 'The process for withdrawing from the European Union', HM Government, 29 February 2016, at 7, para 2.1.

${ }^{15}$ s. 1(4) EU Referendum Act 2015.

16 A post-referendum poll was conducted by Deputy Chairman of the Conservative Party, Lord Ashcroft (How the United Kingdom voted on Thursday... and why' at http://lordashcroftpolls.com/2016/06/how-the-united-kingdomvoted-and-why/). According to this survey, immigration was a secondary motivator for leaving the EU. Of the Leavers polled, most voted out because they believed that 'key decisions about the UK should be taken in the UK.' $20 \%$ of Leave voters did not agree immigration was a force for ill. Such polls are rough tools, and it is very hard indeed to know why voters voted in the way they did. Nonetheless, however important immigration was as a factor for those voting Leave, it is unlikely that of all those who voted in the EU Referendum, a majority were in favour of reducing immigration from the EU.
} 
'To deliver an opinion, is the right of all men; that of constituents is a weighty and respectable opinion, which a representative ought always to rejoice to hear; and which he ought always most seriously to consider. But authoritative instructions; mandates issued, which the member is bound blindly and implicitly to obey, to vote, and to argue for, though contrary to the clearest conviction of his judgment and conscience, these are things utterly unknown to the laws of this land, and which arise from a fundamental mistake of the whole order and tenor of our constitution.' 17

So the referendum, as an expression of popular sovereignty, may sometimes be mistrusted, especially where its results threaten major constitutional change. But perhaps the best antidote to that is not countervailing parliamentary sovereignty (which may also be subject to shorttermism or particular bias) but instead considered constitutional principle, which many countries have set in written constitutions to control major constitutional change, whether instituted by referendum or other form. Without a codified or more substantive constitution, the UK lacks any clear such principles, and it is hard to ascertain what should be the role of referendums in UK constitutional law.

\section{THE TRIGGERING OF ART 50 TEU}

Art 50 TEU, previously little known and less discussed, is now a live issue. Its role in Brexit raises some further questions about sovereignty - although this time, the question is of Parliament's role in an action that appears executive dominated.

Art 50 is the treaty provision that controls the UK's exit from the EU. It was inserted into the Treaty on European Union (TEU) by the Lisbon Treaty amendments in 2009 and gives some details as to how withdrawal negotiations are to be conducted. For example, it states how the EU will conduct its side of the negotiations, that there is a 2-year renewable deadline for the negotiations and provides the voting arrangements by which to reach an agreement (weighted majority) or to extend the deadline (unanimity). Art 50 decides the terms of separation, rather than setting out the details of any UK future trading relationship with the EU, which would be determined in a further agreement.

It appears the UK would now like some time before it gives formal notification under Art 50 TEU. There are advantages in waiting. It will provide time to formulate a negotiating strategy, which at present does not appear to exist. The 2 year limit on withdrawal does not commence until such notification. Once notification has been given, then after 2 years the UK can be ejected from the EU if no Withdrawal Agreement has been concluded and there is no unanimity for extending the time period. On the face of things, the timing of notification seems to be up to UK, although the EU has been urging the UK to act swiftly.

\section{What are 'constitutional requirements' governing a decision of UK to withdraw from EU?}

What about the UK? How is it to conduct its side of the negotiations? The starting point is that Article 50 states that

'1. Any Member State may decide to withdraw from the Union in accordance with its own constitutional requirements.

\footnotetext{
${ }^{17}$ Edmund Burke, 'Speech to the Electors of Bristol', in The Works of the Right Honourable Edmund Burke, (London: Henry G. Bohn, 1854-56). Some have argued, however, that representative politics is under threat in the $21^{\text {st }}$ century. See eg S. Tormey, The end of representative politics (Wiley: Polity, 2015) 'We are moving, remorselessly, away from representation and representative politics towards styles and modes of politics that engage us immediately, directly, now.'
} 
2. A Member State which decides to withdraw shall notify the European Council of its intention...'

What is meant by this reference to the 'constitutional requirements' of the member state concerned? As domestic constitutional matters, these are rightly not dictated by the EU and we need to look at UK constitutional law to see what they are. However, UK Constitutional law is unclear on this matter, partly because there is no codified constitution in the UK specifically dealing with the matter.

First the 'Decision' made by the UK people voting in the referendum is not in itself a 'decision' for purpose of Article 50. ${ }^{18}$ Something more official is needed. The Prime Minister has asserted ${ }^{19}$ that she, or a relevant member of her Cabinet, has the power, using the royal prerogative, to give formal notice to withdraw under Art 50, and that negotiations on the UK's withdrawal would be conducted by Ministers. ${ }^{20}$ But does the UK Parliament have a role? Parliament is involved in the ratification of treaties under Part 2 of the Constitutional Reform and Governance Act 2010, and would in any case inevitably become involved since the European Communities Act (ECA) 1972 would have to be repealed (and possibly replaced with appropriate new legislation).

But could Parliament actually require that its consent is obtained before the Prime Minister can trigger Art 50? This was certainly the view of the House of Lords Constitutional Committee, which in its September 2016 report stated that, 'It would be constitutionally inappropriate, not to mention setting a disturbing precedent, for the Executive to act on an advisory referendum without explicit parliamentary approval-particularly one with such significant long-term consequences. The Government should not trigger Article 50 without consulting Parliament.' ${ }^{21}$ If leaving the EU is about taking back control and regaining parliamentary sovereignty, should not Parliament play a key role in this process?

As there is a large majority of MPs who declared their wish to remain in the EU, the question of who determines whether/when Art 50 should be triggered is certainly relevant. We can also see a growing constitutional convention that prerogative powers are subject to parliamentary approval, as was evidenced by the Commons vote on Syria in August 2013. Furthermore, it is a statute - the ECA 1972 - that sets out in domestic law the UK's relationship with the EU, and EU law's binding effect in the UK, and on withdrawal, Parliament will have to repeal this statute and institute new legislation. Must it therefore authorise the executive to start the unravelling of a process that will lead to the ECA's repeal?

However, in the absence of a codified constitution, and given the application of Art 50, a treaty provision which has never been used before, the constitutional requirements are unclear.

Those arguing for any particular type of constitutional mechanism need to make their case. It is unsurprising that there is litigation on this subject. ${ }^{22}$ There are many different arguments ${ }^{23}$

\footnotetext{
${ }^{18}$ Indeed, the European Parliament erred when it stated in its Resolution of 28 June 2016, that if the UK Prime Minister were to notify the June European Council of the referendum 'outcome' that would 'launch the withdrawal procedure.' (European Parliament, 'Outcome of the referendum in the United Kingdom,' European Parliament resolution of 28 June 2016 on the decision to leave the EU resulting from the UK referendum (2016/2800 (RSP)). 19 'Theresa May will trigger Brexit negotiations without Commons vote', The Telegraph, 26 August 2016, http://www.telegraph.co.uk/news/2016/08/26/theresa-may-will-trigger-brexit-negotiations-without-commons-vot/ ${ }^{20}$ Or civil servants, diplomats, and possibly others.

${ }^{21}$ 'The invoking of Article 50 on the Constitution', House of Lords Select Committee on the Constitution, 4th Report of Session 2016-1 at 8.

${ }^{22}$ See on this, eg J. Maugham QC, 'Brexit: an important role for the courts', Counsel, 7 September 2016.

23 See inter alia, N. Barber et al., 'Pulling the Article 50 "Trigger": Parliament's Indispensable Role', https://ukconstitutionallaw.org/2016/06/27/nick-barber-tom-hickman-and-jeff-king-pulling-the-article-50-triggerparliaments-indispensable-role/; see also S. Styles, 'What is Sufficient to Constitute an Article 50 Decision to Leave the EU?', https://aberdeenunilaw.wordpress.com/2016/06/27/what-is-sufficient-to-constitute-an-article-50decision-to-leave-the-eu/; A. Tucker, 'Triggering Brexit: A Decision for the Government, but under Parliamentary Scrutiny', U.K. Const. L. Blog (29th Jun 2016) (available at https://ukconstitutionallaw.org/); T. T. Arvind, R. M. Kirkham and L. Stirton, 'Article 50 and the European Union Act 2011: Why Parliamentary Consent is Still Necessary’ U.K. Const. L. Blog (1st Jul 2016) (available at http://ukconstitutionallaw.org))
} 
that have been advanced, and for reasons of space, they cannot all be given consideration here. In what follows, the case will be made for parliamentary involvement in the decision to trigger Art 50.

\section{The prerogative and treaty making}

The royal prerogative comprises those rights of the Crown which originate in the archaic common-law privileges of the monarch rather than from a legal grant of authority by Parliament. The royal prerogative exists by tradition and custom, not by any officially writtendown code or constitution, and it has proved difficult to give a comprehensive catalogue of prerogative powers. However, Bradley and Ewing in their summary of the main areas of prerogative use today suggest that it incudes powers relating to foreign affairs, e.g. - the making of treaties, the declaration of war and the making of peace; restraining aliens from entering the UK and the issue of passports. ${ }^{24}$ As Dicey defined it: 'Every act which the executive government can lawfully do without authority of an Act of Parliament is done in virtue of this prerogative.' ${ }^{25}$ If we follow Dicey then, a key question is whether the Government can trigger Art 50 lawfully without an Act of Parliament?

It is undisputed that a consequence of the Glorious Revolution was the establishment of the parliamentary right to control all of the Crown's prerogatives through parliamentary sovereignty. ${ }^{26}$ The prerogative is a residual power source, whose specific instances may be deliberately replaced by Parliament. Theresa May and others assert the prerogative is still the appropriate way to trigger Art 50 based on the fact that the prerogative traditionally includes powers relating to foreign affairs, such as treaty negotiation. However, there is now a growing argument that employment of the prerogative, even as a residual source of constitutional power, is problematic. As early as 1872, Walter Bagehot, argued that treaties could be just as significant as legislation. He also made the point that, while the consent of Parliament was required for 'every word of the law', such approval was not required 'even as to the essence of the treaty', a situation that he found 'prima facie, ludicrous' ${ }^{27}$ Indeed, as Blick and Gordon remind us, it was the perception that secret agreements helped trigger the First World War that led to the development of a convention ('the Ponsonby rules') whereby some parliamentary scrutiny of treaties was introduced prior to ratification..$^{28}$

There have been various attempts to reform the prerogative, including the 2007 Government Governance of Britain Green Paper which suggested that 'prerogative powers should be put onto a statutory basis and brought under stronger parliamentary scrutiny and control. ${ }^{29}$ This review specifically intended to reform prerogative powers to ratify treaties, ${ }^{30}$ but these reforms did not come about (although they found partial reflection in some provisions of the Constitutional Reform and Governance Act 2010). Furthermore, the policy behind the EU 2011 Act, which mandated referendums and statutory confirmation of any EU treaty amendments with a significant impact for the UK, was in the words of then Foreign Secretary, William Hague, 'a fundamental shift in power from Ministers of the Crown to Parliament and the voters themselves on the most important decisions of all: who gets to decide what ${ }^{31}$ on European integration, so that executive action in their absence would be clearly

\footnotetext{
${ }^{24}$ A.W. Bradley and K.D. Ewing, Constitutional and Administrative Law, 13th Ed, (Longman: 2003), 105 \& 246247.

${ }^{25}$ A. V. Dicey, Introduction to the Study of the Law of the Constitution, 10th edn, (London, Macmillan: 1959) 424.

${ }^{26}$ Jeffrey Goldsworthy: The Sovereignty of Parliament. History and Philosophy (Oxford: Clarendon Press, 1999), 159-160, 232.

${ }^{27}$ Walter Bagehot, The English Constitution, 1867 (Oxford World's Classics: 2001) 39. Although treaties that required a change in domestic legislation had to be approved by Parliament.

${ }^{28}$ See further: A Blick, 'Emergency powers and the withering of the Royal Prerogative', 18 International Journal of Human Rights (2014).

${ }^{29}$ Ministry of Justice, The Governance of Britain Green Paper, Cm 7170, July 2007, para 24.

${ }^{30} \mathrm{Ibid}$, paras 31-33.

${ }^{31}$ per William Hague MP, when introducing the EU Act for second reading as a Bill on 7 December 2010 (Hansard, HC Volume 520, Col. 193).
} 
unconstitutional. So there is evidence of a shift from use of the prerogative to something perceived as more democratic.

Blick and Gordon suggest that a new constitutional norm may be developing whereby the prerogative may not be used for important government activities. As they articulate it, the norm is that, 'in general, statutory authority is preferable to, and constitutionally more appropriate than, prerogative authority as a basis on which to carry out actions of major importance, including those that entail significant constitutional change. ${ }^{32}$

Taking this point further, it is important to stress that negotiating EU withdrawal is not just any old treaty negotiation. Lord Denning famously compared the impact of EU law in the UK to an incoming tide flowing up the UK legal system, with an undeniably profound impact. ${ }^{33}$ The extrication of the UK from the EU, and EU law, is of immense magnitude and significance, and it requires major constitutional changes in the UK, and institutional changes for the EU. The former British judge at the CJEU, Sir David Edward, said: '[W]ithdrawal from the Union would involve the unravelling of a highly complex skein of budgetary, legal, political, financial, commercial and personal relationships, liabilities and obligations. ${ }^{34}$ Brexit would require that UK nationals lose their EU citizenship - a legal change whose implications has not yet been fully investigated. Brexit would also mean loss of rights enshrined in EU law, unless the UK agreed to maintain these in domestic law. EU law has created vast networks of rights and obligations, not only between Member States, but also for nationals of those States. The subject matter of these rights - trading rights, free movement rights, social rights, nondiscrimination rights, fundamental rights - covers many matters central to individual liberty, and their repeal or amendment, even by means of primary legislation, would be highly controversial. Over the longer term, disentangling the UK from the substantial body of EU legislation which applies in the UK would be a massive task, which would take many years to complete. Some have proposed the use of a 'Henry VIII clause' to abolish many of these rights en bloc. ${ }^{35}$ Such a procedure, using a ministerial order, with minimal or no parliamentary scrutiny, undermines fundamental rights, but is also undemocratic and detrimental to the parliamentary sovereignty that those who wish to leave the EU are so fond of proclaiming (because repeal, retention or amendment by statutory instrument removes chances for parliamentary debate, limiting action instead to the Executive).

Therefore, triggering Art 50 is a momentous step, given the impact it would have on domestic law and in particular on rights. In these circumstances, we can distinguish UK withdrawal from the EU from the usual run of treaty negotiations and there is a very strong case for parliamentary involvement. As a result, some commentators argue not just for the existence of a convention of parliamentary involvement, but for an actual legal requirement for legislation before exercise of prerogative powers. ${ }^{36}$

\section{Is legislation necessary to trigger Art 50?}

The arguments run along the following lines. A starting point is that the UK enabled its accession to the EEC to be ratified by means of the ECA 1972. Under British law, a statute may only be repealed by another statute, and not by the exercise of prerogative power. ${ }^{37}$

\footnotetext{
${ }^{32}$ A. Blick and R. Gordon, 'Using the prerogative for major constitutional Change: The United Kingdom Constitution and Article 50 of the Treaty on European Union', The Constitution Society Paper, available at http://www.consoc.org.uk/wp-content/uploads/2016/08/Royal-Prerogative-paper-Andrew-Blick-Richard-GordonPDF.pdf at 6.

${ }^{33}$ Bulmer (HP) Ltd $v$ J Bollinger SA [1974] Ch 401 at 418-19.

34 'Leaving the EU' House of Commons Library (2013) RP 13/42 10.

${ }^{35}$ see eg the suggestions of M. Howe QC, in 'Zero Plus: The Principles of EU Renegotiation' (Politeia: 2014) at 7.

36 Eg N. Barber et al., 'Pulling the Article 50 "Trigger": Parliament's Indispensable Role', https://ukconstitutionallaw.org/2016/06/27/nick-barber-tom-hickman-and-jeff-king-pulling-the-article-50-triggerparliaments-indispensable-role/.

${ }^{37}$ see eg Case of Proclamations (1611) 12 Co. Rep. 74, 75; R. v. Secretary of State for the Home Department, ex parte Fire Brigades Union and others [1995] 2 AC 513, 552.
} 
However, as the actual effect of Art 50 notification would be to trigger a 2 year timeline at the end of which the UK would cease to be an EU member state, ${ }^{38}$ triggering Art 50 in fact nullifies the effect of the ECA in UK law. The prerogative cannot be exercised in a manner which would 'turn a statute into what is in substance a dead letter' or 'cut across the object and purpose of an existing statute'. ${ }^{39}$

Furthermore, because only Parliament may limit or abrogate rights (consistently with the common law principle of legality) it follows that Art 50 may, because of its ultimate effect on rights, only be triggered by Parliament. ${ }^{40}$ Clearly, if the UK had not held a referendum, the Government could not have abrogated the rights and responsibilities in the ECA by withdrawing from the EU by unilateral, executive act, and the UK Referendum Act 2015 provides no explicit authority for amendment or repeal of the ECA. As already discussed, it was an advisory not a mandatory referendum. These rights-related arguments are confirmed by Lord Oliver, who stated in Rayner (Mincing Lane) v DTI: 'as a matter of the constitutional law of the United Kingdom...the Royal Prerogative, whilst it embraces the making of treaties, does not extend to altering the law or conferring rights upon individuals or depriving individuals of rights which they enjoy in domestic law without the intervention of Parliament. ${ }^{41}$

Lastly, there are precedents for securing parliamentary consent for matters where there exists doubt about scope of the prerogative. As Arvind and others point out, precedent may be found in the transfer of Heligoland to Germany, where parliamentary consent was expressly sought, despite the majority view that ceding this territory fell within the prerogative. ${ }^{42}$

It therefore follows that it would be necessary for an Act of Parliament to provide the authority for Art 50 notification (and prospective repeal of the ECA two years after making the notification).

Now there is resistance to these arguments. It is contended that the argument that, by triggering Art 50, the Prime Minister would be taking power to 'prospectively repeal' the ECA, is incorrect. Alison Young, for example, has argued that it is 'hard to read Art 50 as requiring that the only possible outcome is a Withdrawal Agreement or removal of the UK from the EU. Art 50...is silent on whether member states may withdraw the decision to leave the EU before then. ${ }^{43}$ But as David Pannick argues, 'the crucial point is that, as a matter of law, Article 50 notification commits the UK to withdrawal from the EU, and so is inconsistent with the 1972 act. ${ }^{44}$

In any case, this matter is the subject of litigation. Traditionally, the courts have shown deference to the executive in the foreign policy arena, and UK courts have declined to become involved in matters of treaty making, ${ }^{45}$ and one might expect the Government to argue that Art 50 was an area where the courts should be slow to engage. Lord Bingham noted in $R$ (Gentle) $v P M$ the 'restraint traditionally shown by the courts in ruling on what has been called high

\footnotetext{
38 either by conclusion of a Withdrawal Agreement within that period, or by expiry of the deadline in Art 50, unless an extension is agreed by all EU states by unanimity.

${ }^{39}$ ex parte Fire Brigades Union and others [1995] 2 AC 513, 552.

${ }^{40}$ See also Laker Airway v Department of Trade [1977] QB 643.

${ }^{41}$ Rayner (Mincing Lane) v DTI [1990] 2 AC 418, 462.

${ }^{42}$ T. T. Arvind, R. M. Kirkham and L. Stirton, 'Article 50 and the European Union Act 2011: Why Parliamentary Consent is Still Necessary' U.K. Const. L. Blog (1st Jul 2016) (available at http://ukconstitutionallaw.org)). The treaty was deliberately made subject to parliamentary consent, which was obtained through the Heligoland Act 1890. They note that 'This sound constitutional practice, motivated by desire to avoid constitutional crises that might otherwise result, commends itself for adoption in relation to Art 50.'

${ }^{43}$ A.L. Young, 'Brexit, Article 50 and the 'Joys' of a Flexible, Evolving, Un-codified Constitution' U.K. Const. L. Blog (1 Jul 2016) (available at http://ukconstitutionallaw.org). See also M. Elliott, 'On Why, as a Matter of Law, Triggering Article 50 Does not Require Parliament to Legislate', https://publiclawforeveryone.com/2016/06/30/brexit-on-why-as-a-matter-of-law-triggering-article-50-does-notrequire-parliament-to-legislate/.

${ }^{44}$ D. Pannick, 'Why giving notice of withdrawal from the EU requires act of parliament', The Times, 30 June 2016.

${ }^{45} R v$ Secretary of State for Foreign and Commonwealth Affairs ex parte Rees-Mogg [1994] Q.B. 552, CA.
} 
policy - peace and war, the making of treaties, the conduct of foreign affairs' ${ }^{46}$ However, a main feature of the current lawsuit is whether prerogative power exists at all in this context. The De Keyser case ${ }^{47}$ established clearly that courts may determine whether prerogative power exists and, if so, its scope, and the extent to which it can be displaced by statute. Similarly, in $G C H Q$, Lord Fraser stated; 'the courts will inquire into whether a particular prerogative power exists or not and, if it does exist, into its extent. ${ }^{48}$

\section{Constitutional reality?}

But in any case, as Blick and Gordon argue, constitutional reality does not necessarily depend for legitimacy on a single answer to a question of law, but rather on the nuanced considerations of constitutional practice over time. Even if the court action should fail, so that legislation prior to triggering Article 50 is not a legal requirement, there are important reasons, rooted in democracy, which support the argument that Parliament should play a full part in discussions. As is becoming obvious, the withdrawal process, and extricating the UK from the $\mathrm{EU}$, involve a huge range of complex issues in virtually every area of public life, which were not determined by the binary referendum vote, nor since answered.

Once Art 50 TEU is triggered, absent safeguards for further parliamentary control, the UK's withdrawal negotiations, and framework talks for future EU relations, are likely to be conducted according to the usual practice under the prerogative. This is hardly a transparent process. Parliament has not traditionally had a major (or indeed any notable) role in foreign and trade negotiations. Both government ministers and unelected and unaccountable officials conduct the negotiations behind closed doors. The process is opaque and secretive. It has been exceptionally hard for Parliament to access information in advance of negotiations, and virtually impossible for it to play a part in shaping government's position. This is in contrast to the position in other countries such as Denmark and Finland. For example, in June 2007, at the time of government negotiations in advance of what would become the Lisbon treaty, it proved almost impossible for Parliament to gain information about the government's negotiating position. Margaret Beckett, then Foreign Secretary stated, 'One of the conclusions that I have come to is that the less I say about what we might in principle accept and what we might not, the more I preserve the maximum amount of negotiating space to resist anything that I think is not in Britain's national interest. I appreciate that is unsatisfactory for the committee. ${ }^{, 49}$

There was a similar lack of information and consultation of both the UK Parliament and the devolved institutions during David Cameron's 2015/16 negotiations over a 'New Settlement' for the UK with Donald Tusk, a fact specifically noted by the House of Lords EU select committee in its report on the EU Referendum and Reform. ${ }^{50}$ This does not bode well for communications to the UK Parliament and devolved institutions on any Withdrawal Agreement.

Of course, Parliament will have to ratify whatever Withdrawal Agreement is concluded under Art 50. So, for example, back in the early 1970s, the UK government negotiated its EEC accession (using prerogative powers) and Parliament debated and assented to the Treaty of Accession under the former Ponsonby rules, as well as passing the ECA, and the UK joined the (then) EEC on 1st January 1973. The Brexit agreement will probably be governed by the Constitutional Reform and Governance Act (CRAG) 2010 (which replaces the former Ponsonby rules), although it is possible that the EU Act 2011 might control the matter, in

\footnotetext{
${ }^{46} R$ (Gentle) v Prime Minister [2008] 1 AC 1356 at [8].

${ }^{47}$ Attorney General v De Keyser's Royal Hotel [1920] AC 508.

${ }^{48}$ Council of Civil Service Unions v Minister for the Civil Service [1985] AC 374, 398.

${ }^{49}$ House of Commons, Select Committee on European Scrutiny, Minutes of Evidence, Thursday 7 June 2007, answer to Q 28 .

${ }^{50}$ House of Lords European Union Committee, 3rd Report of Session 2015-16, 'The referendum on UK membership of the EU: assessing the reform process,' HL Paper 30, pp 13 and 20.
} 
which case a referendum might also be required. Section 20 of CRAG states that if the House of Commons resolves within 21 days that the treaty should not be ratified, then subject to certain exceptions, it would be unlawful to do so. This rule prevents the executive from committing the UK at international level through ratification of a treaty of which Parliament disapproves.

However, the situations of UK EEC accession and EU withdrawal raise very different issues of parliamentary involvement. The problem is that if Parliament refuses to ratify a Withdrawal treaty with the EU, it will be too late for Parliament to insist on its own conditions. It will be presented with a done deal on a 'take it or leave it' basis. The EU could simply state that, in the event of no agreement being concluded, and Art 50's 2 year time period expiring, the UK should withdraw with no agreement, a situation hardly likely to favour the UK. A withdrawal agreement is different to an accession treaty or a new treaty (such as the Lisbon treaty) expanding EU powers. In these latter cases, if under domestic law ratification is not possible (as in the case of a Norwegian No vote to enter the EEC, or the Irish peoples' first No vote on the Lisbon Treaty) renegotiation often goes ahead (although requires unanimity) but in the meantime the status quo continues. In the case of withdrawal, Art 50 TEU also requires unanimous agreement of other EU states to continue negotiation beyond 2 years, but unlike in the other examples, the status quo does not continue, instead the treaties cease to apply. This would mean a huge (legal) change for the UK and loss of individual rights, which is hardly to maintain the status quo.

This is why it is vital that Parliament maintains some control on the process. There is no reason, for example, why EEA membership should be off the table. Neither domestic law nor politics dictates this. However, there is a danger that those negotiating the Brexit withdrawal from the UK will dictate its terms, and once Art 50 is triggered, they will have a great deal of discretion under the prerogative to do so. If the current lawsuit brought against the UK government, requiring an Act of Parliament before Art 50 TEU is triggered, succeeds, then such an Act could set down conditions for negotiating the terms of Britain's exit. Otherwise, there is no guarantee that Parliament will be kept regularly informed of negotiation progress, nor of the terms sought. This will not mean 'taking back control' for Parliament. 'Brexit means Brexit' may well mean dominance by the executive of the day, and its political purposes. This state of affairs reveals the weaknesses and paradoxes of parliamentary sovereignty. Parliament is in fact subjected to the executive in many instances. It is only in its statutory competences that it is sovereign.

Parliamentary control in the Art 50 context need not mean blocking or voting down Brexit. Instead, it could safeguard the crucial functions of Parliamentary scrutiny and holding the government to account in the withdrawal process. ${ }^{51}$ For all that the UK has experimented with direct democracy through the holding of a referendum, the UK remains, fundamentally, a parliamentary democracy, and it cannot plausibly be argued that the referendum substitutes for proper parliamentary involvement.

\section{Is there an alternative to Art 50 TEU?}

A further example illustrates a different conundrum of sovereignty, and further constitutional confusion. The possibility of ignoring Art 50 altogether has been canvassed by some Brexit campaigners. For example, John Redwood, MP was reported in the Financial Times as

\footnotetext{
${ }^{51}$ As Hazel and Sheldon remind us ('What role will parliament have in triggering Article 50 and shaping the terms of Brexit?' The Constitution Unit blog, July 19, 2016) 'When the legislation to abolish the Greater London Council was going through parliament in the mid-1980s, Tony Banks MP, the former chairman of the GLC, tabled hundreds of parliamentary questions asking how various parts of London would be administered under the new arrangements. It was clear from the slow stream of answers he received, that many of the implications had not been thought through and policy was being made up on the hoof as he raised each new issue.'
} 
suggesting that 'a lot of us don't think there is any need to trigger Article 50 any time at all. ${ }^{52}$ $\mathrm{He}$ has advocated changing UK law by, for example, repealing the ECA 1972 (without triggering Art $50 \mathrm{TEU}$ ) and so unilaterally ending the application of EU law in the UK. Similar variations have been mentioned by other pro-Leave campaigners, such as the adoption of UK legislation declaring that the UK will leave the EU on a certain date, as well as legislation addressing particular aspects of EU law, such as curtailing the power of EU judges and changing rules on EU migration. This suggests that Parliament can take control of the withdrawal process, enacting its own legislation, and short-circuiting the need to follow Art 50 treaty procedures and EU law. Domestic law rather than EU, or international law, is seen as governing withdrawal. This suggests a strong parliamentary sovereignty, governing all things, including our relations with other states, and the ability to unilaterally ignore our treaty obligations.

We should be very clear that, if taken prior to (or in the absence of) formal withdrawal from the EU treaties under Art 50, such actions would clearly violate both EU law and international law. To take EU law first - adopting national primary legislation in breach of EU law would have repercussions. Although there is no mechanism in the EU treaty whereby a member state may be ejected from the EU against its will, Art 7 TEU permits the EU to suspend the membership of a state, where it is found to breach EU values in Art 2 TEU (which include non-discrimination, which would certainly be at issue if the UK suspended EU citizens' rights in the UK). Art 7 TEU, like Art 50, has never been used, and its procedures are quite involved and in any case, it might be said, that if the UK is withdrawing anyway, what objection could it make to suspension of its membership? Nevertheless, if the very first activation of Art 7 TEU (a procedure that was introduced by the EU to deal with the perceived threat of Jorg Haider's far-right Freedom party in Austria) were against the UK, this would be an uncomfortable message for the UK to bear, suggesting that it deliberately violated values such as freedom, democracy and the rule of law. Aside from Art 7 TEU, violation of EU law by the UK would open it to enforcement actions being brought against it by the European Commission under Art 258 TFEU (or indeed by another member state which felt that its citizens had been discriminated against under Art 259 TFEU). There is provision for financial sanctions to be imposed in such a case, which could be considerable. ${ }^{53}$

Further, any national legislation deliberately violating EU treaties would be unlawful in international law and harmful to the UK's reputation. All treaties involve some voluntary restriction on our freedom of sovereign action (which states have accepted). That includes particular stipulations for renunciation and withdrawal from treaties. As former UK AttorneyGeneral Dominic Grieve wrote in The Times Legal Brief:
'So in arguing that the UK should simply tear up our EU treaty obligations by using parliament to enact legislation in breach of them, the Brexiteers, including our Lord Chancellor, who takes a special oath to uphold the rule of law, are proposing something revolutionary and lawless. It would send the clearest message to the world that our long stated policy of observing the terms of international treaties is finished. No reliance could henceforth be placed on our honouring any international obligation. ${ }^{54}$

The attempt to use national legislation to revoke EU membership also confuses sovereignty. It conflates parliamentary sovereignty with external sovereignty, suggesting that the UK can use Parliament and domestic law to govern its relationships with other states and international organisations under treaties, because of some misplaced idea of parliamentary sovereignty. That is not how national sovereignty functions in the international arena. States observe treaties and join international organisations because they know that in ceding some freedom in

\footnotetext{
52 'EU's Article 50 could become first Brexit stand-off,' Financial Times, 24 June 2016, at http://www.ft.com/cms/s/0/7badcbe2-3a0b-11e6-9a0582a9b15a8ee7.html?siteedition=intl\#axzz4JsFxXJAT.

${ }^{53}$ For example, the Commission referred Italy to the ECJ for its failure to implement rules on animal testing in its domestic legislation and asked for penalty payments of EUR 150787 per day, see Press release of the European Commission: http://europa.eu/rapid/press-release_IP-14-46_en.htm

${ }^{54}$ Dominic Grieve QC, 'Brexiteers are proposing an illegal EU exit', The Times Brief, June 17, 2016.
} 
certain areas, they are actually gaining a greater benefit from pooling sovereignty or accepting certain obligations. There are rules set out in international law, and in treaties, as to how these obligations function and states cannot simply assert parliamentary sovereignty to circumvent them.

\section{DEVOLUTION}

The example of Devolution provides a final example of how Brexit poses challenges to which the British Constitution cannot provide determinative answers. I have suggested elsewhere that Brexit poses an existential threat to the EU. ${ }^{55}$ In the referendum on the UK's EU membership, the UK as a whole voted to leave. However, $62 \%$ of Scotland's voting electorate voted to remain. Yet the devolved nations have no formal role in Art 50, and thus no means of ensuring that their constitutional interests are protected.

Consideration of the position of the devolved nations ${ }^{56}$ reveals another fissure in the way the British Constitution is understood. There are very different interpretations at issue. Let us see the shape they take, and how they contrast.

\section{One view of the British Constitution}

From the perspective of the UK Government, the British constitution is unitary in nature, with certain key elements. Foreign affairs is a reserved matter under Schedule 5 of the Scotland Act 1998, and this includes EU membership. Devolved authorities have no legal rights in this area, and, at most, may be consulted as a matter of courtesy or goodwill. Neither EU law (Article 50 TEU) nor UK law (the Devolution Acts) guarantees Scotland a specific role in withdrawal negotiations nor in any parallel negotiations on EU-UK post-exit relationship. ${ }^{57}$ This also meant that David Cameron could renegotiate Britain's EU membership with European Council President, Donald Tusk, without having to secure the agreement of the devolved nations.

Along with the reservation of foreign affairs, as we have seen, the UK Government approaches treaty-making as a matter of the royal prerogative. It accords the UK Parliament no formal role in the withdrawal process, although legislation enabling ratification of the withdrawal treaty would have to be lodged in Parliament after an agreement was reached. But couple this dominance of the executive (at the expense of Parliament), with the contrasting assertion that the Westminster Parliament is sovereign and has legislative competence in all matters (including even devolved ones), and we see the tensions underlying this view of the Constitution. It views the UK as a unified, centralised state, with an omnicompetent Parliament. (But it has also sought to subjugate Parliament to the executive in the Art 50 process).

Scotland voted for the UK to remain in the EU. Notwithstanding, according to prevailing interpretations of the referendum result, the Scottish result could be ignored. The SNP tabled an amendment to the EU Referendum Bill, requiring that for the UK to leave the EU, each of the four constituent nations - England, Scotland, Wales, and Northern Ireland - would have to vote to do so, not just the UK as a whole, and Nicola Sturgeon confirmed this call for a 'double majority lock' on a number of occasions.$^{58}$ In making this point, the aim was to ensure that none of the UK nations would be removed from the EU against their will. However,

\footnotetext{
${ }^{55}$ S. Douglas-Scott, 'British withdrawal from the EU: an existential threat to the United Kingdom?' U.K. Const. L. Blog (13 October 2014) (available at http://ukconstitutionallaw.org).

${ }^{56}$ For reasons of space this article focusses on Scotland, while acknowledging that Scotland, Wales and Northern Ireland may not necessarily have shared objectives.

57 The Concordat on Coordination of EU Policy states that Scottish Ministers and Officials are to be fully involved in discussions within the UK Government on UK policy on all devolved issues, but this is not legally binding (Memorandum of Understanding and Concordats on Coordination of European Union Policy Issues, October 2013). ${ }^{58}$ I. MacWhirter, 'A Federal Bomb is Dropped into More-Powers Debate', The Herald, 30 October 2014.
} 
Sturgeon was also emphasizing a point made by Westminster leaders during the Scottish referendum campaign - that the UK is a 'family of nations', with equal status for each of the family members. ${ }^{59}$ Sturgeon's point was that to withdraw the UK from the EU, against Scotland's will, would be 'democratically indefensible'. In making this case, Sturgeon drew some comparisons: 'If you look at states like Australia and Canada there are some circumstances where changes to their constitution requires not just a majority across the country but in each of the provinces as well ...Germany requires its Länder to sign off on changes to the Basic Law, through a two-thirds vote in the Bundesrat. So you can see that such double majorities do exist. ${ }^{60}$ However, the amendment requiring a "double majority lock' was rejected, and David Cameron stated in the House of Commons in 2014 that: 'We are one United Kingdom, there will be one in/out referendum and that will be decided on a majority of those who vote. That is how the rules should work. ${ }^{61}$

This reveals a contrast in the constitutional approaches of London and Edinburgh. David Cameron presented a view of the UK as a unified state, and the referendum vote was counted UK wide, with no attention to regional variation. On this view, Scotland's (or Northern Ireland's) vote to remain in the UK has no constitutional relevance.

\section{Another view of the Constitution}

However, this view expressed by David Cameron, now upheld by the present UK government, contrasts with that held by many in the devolved nations and also by some in England. This alternative approach identifies other traditions and interpretations as key to an understanding of the British constitution, and views the UK as a union state rather than a unitary state. It interprets the UK as a union founded on treaties (such as the Treaty of Union 1706) and reliant on ongoing consent, as well as on constitutional practice which involves much (ie constitutional conventions) that is not strictly speaking law.

This alternative interpretation of the British Constitution also recognises that the UK has been transformed, or even revolutionised, by external developments and memberships (such as the EU and Council of Europe) and recalibrated internally by devolution arrangements since 1998 (but also by the Human Rights Act, and a desire for a more principled constitutional development than parliamentary sovereignty allows). ${ }^{62}$ We see the example of the Scotland Act 2016 declaring the permanence of the Scottish Parliament, a provision which, if it is to have any meaning, flies in the face of orthodox constitutional law's assertion of parliamentary sovereignty. We also see a concept of the decentralised and fragmented state at work in Northern Ireland, where the Good Friday agreement sets out complex provisions regarding cross-community consent, self-determination, and also a role for the Republic of Ireland (and the EU).

Furthermore, the contention that EU membership is a matter of foreign affairs and thus reserved, might also be challenged. EU law (unlike most international law and treaties) is engrained in UK law, and has become part of our very domestic legal system, including the devolution settlement and devolved laws. Many EU competences are in areas that have been devolved - such as agriculture or fisheries - and post Brexit would be matters for devolved governments and parliaments. In many federal or otherwise devolved states, the notion that central government can employ the cover of foreign treaties to invade devolved competences has been very controversial. So for example, under the US Constitution, the President has full power to make treaties. However, to become valid in constitutional law, such treaties require the concurrence of $2 / 3$ of the Senate present, and there are certain limits on federal treaty

\footnotetext{
59 'PM begs Scots not to break up "Family of Nations" ', Reuters, September 10, 2014.

${ }^{60}$ N. Sturgeon, speech, 29 October 2014, discussed at <http:// www.heraldscotland.com/ comment/ columnists/ afederal- bomb- is- dropped- into- more- powers- debate.25721371>.

${ }^{61}$ Hansard, Commons Debates, 29 October 2014, Column 301.

${ }^{62}$ As evidenced, for example, by the creation of institutions such as the House of Lords Constitution Committee.
} 
power requiring that it not encroach on the constitutional autonomy of the States. ${ }^{63}$ Under the German Constitution, 'relations with other states are...conducted by the Federation' (Art. 32 Sec. 1), but Länder specifically concerned must be consulted. Under the principle of federal loyalty or comity (Bundestreue) the Federal Government is obliged to take into account the opinion of the Länder.

A British exit from the EU is sometimes justified in terms of the maintenance of parliamentary sovereignty, which presently must concede the supremacy of EU law. ${ }^{64}$ Yet the Diceyan vision of parliamentary sovereignty is under challenge in the UK in any case. For example, Lord Hope stated in the Jackson case that, 'Parliamentary sovereignty is no longer, if it ever was, absolute. [...] Step by step, gradually but surely, the English principle of the absolute legislative sovereignty of Parliament ... is being qualified. ${ }^{65}$ In any case, the Diceyan orthodoxy never held as much weight north of the border. In the 1953 case of MacCormick $v$ Lord Advocate in the Court of Session, the Lord President, Lord Cooper, (a former Conservative and Unionist politician and eminent legal historian) contested the Diceyan orthodoxy thus: 'The principle of the unlimited sovereignty of parliament is a distinctively English principle which has no counterpart in Scottish constitutional law.' 66

Linda Colley's well-known work, Britons: Forging the Nation ${ }^{67}$ reminds us that both the British state and the British national identity were 'forged' by the Acts of Union of 1707. The United Kingdom is only 300 years old, not an ancient natural phenomenon, and it may be undone. Given that the Union of 1707 brought into being the British state, ought we not give this historical event of the Acts of Union its due as a keystone of the British constitution, rather than the Diceyan mantra of parliamentary sovereignty? In which case, perhaps we should recognise that the British constitution is not simply the English constitution, and that Scottish constitutional principles (and Northern Irish, and even now nascent Welsh ${ }^{68}$ ) play their part in a multiple constitutional order, and may be of particular salience at times of crisis or 'constitutional' moments, such as the issue of whether to withdraw from the EU. Scottish intellectuals, lawyers and politicians of many different political persuasions stand by an indigenous Scottish tradition of popular sovereignty that is claimed to date back to the Declaration of Arbroath in 1320. They hold that, before the 1707 Act of Union, sovereignty resided in the Scottish people - and that it still does so, in spite of the claims of Diceyan parliamentary sovereignty.

Therefore, meditation on the entirety of the Union, and its constitutional basis, poses the question of whether, at least in Scotland, the doctrine of popular sovereignty might form the basis of Scotland's own right to determine whether or not it exits the EU. After all, much has been made of the issue of 'popular sovereignty' in the context of the EU referendum result. Yet, once again, there is constitutional confusion. What reason is there to respect popular sovereignty in the guise of the EU Referendum, when the UK has no recognizable tradition of popular sovereignty, nor any great tradition of holding referendums, if popular sovereignty is ignored in the context of the Scottish vote, where there is a much clearer tradition of the sovereignty of the people in Scotland?

\footnotetext{
${ }^{63}$ See Art. II Sec. 2 Cl. 1 US Constitution. In Bond v US 131 S. Ct. 2355 (2011), a unanimous Supreme Court held that a litigant had standing to argue that a federal statute enforcing the Chemical Weapons Convention intruded on areas of police power reserved to the states (although the claim did not ultimately succeed).

${ }^{64}$ Acknowledged both in European Court caselaw such as Costa $v$ ENEL, and s 2(4) ECA 1972.

${ }^{65} R$ (Jackson) v Attorney General [2006] 1 AC 262, per Lord Hope at 104.

${ }^{66}$ MacCormick v Lord Advocate 1953 SC 396, 1953 SLT 255.

${ }^{67}$ L. Colley, Britons: Forging the Nation, 1707-1837 (Vintage: 1996).

${ }^{68}$ See for example, the 'Welsh Byelaws' case: Attorney General v National Assembly for Wales Commission and others [2012] UKSC 53.
} 


\section{Legislative consent}

If such questions are ignored, and one particular view of the Constitution unilaterally imposed, we risk constitutional crisis. This is illustrated by the issue of legislative consent. EU law is incorporated directly into the devolution statutes in Scotland, Wales and Northern Ireland. For example, section 29(2)(d) Scotland Act 1998 provides that Acts of the Scottish Parliament that are incompatible with EU law or with ECHR rights are 'not law' ${ }^{9}{ }^{69}$

Therefore, although Westminster may repeal the ECA 1972, this would not bring an end to the domestic incorporation of EU law (or the ECHR) in devolved nations. It would still be necessary to amend the relevant parts of devolution legislation. But this would be no simple matter and could lead to a constitutional crisis. Although the UK Parliament may amend the devolution Acts, the UK government has stated that it will not normally legislate on a devolved matter without the consent of the devolved legislature. This requires a Legislative Consent Motion under the Sewel Convention, according to which Westminster does not legislate in devolved matters nor, by extension, amend the competences of the devolved institutions, except with their consent. After the 2014 Scottish independence referendum, unionist parties agreed to entrench this convention as securely as possible, and it is set down in the Scotland Act $2016 .^{70}$ To be sure, the provision is that Westminster will not 'normally' invade devolved competences without their consent, and much has been made of this. But if 'normally' simply means the UK Government's stipulated interpretation of the term, then the provision is pointless. Legislative consent motions only make sense if they go beyond trifling and commonplace issues. And, if Westminster were to ask for legislative consent to amend the Scotland $\mathrm{Act}^{71}$ in the context of Brexit, Nicola Sturgeon has made clear that she would 'of course' ask the Scottish Parliament to withhold consent in order to prevent Scotland being taken out of the EU against its will. ${ }^{72}$

What if the UK Government were simply to press ahead with such legislation, ignoring refusal of legislative consent? The entrenchment of (at least parts) of the Sewel Convention in the Scotland Act 2016 would set the UK Government in breach of statute, if it took this course. And even if we simply see the requirement of consent as a convention, ${ }^{73}$ the Government would be in breach of a major constitutional rule. Constitutional conventions were seminally defined by Wheare as 'a rule of behaviour accepted as obligatory by those concerned in the working of the constitution. ${ }^{74}$ They are binding. It is clearly unconstitutional to disregard conventions, and actions that violate them can have considerable political and constitutional consequences. For example, in 1982, then Canadian Prime Minister, Pierre Trudeau, 'patriated' the Canadian Constitution across the entirety of the country against the wishes of the Quebec government, (which claimed the existence of a convention requiring their consent), destabilising relations between Canada and Quebec for many years, and triggering independence referendums in Quebec. A comparable convention applying in the context of the UK Parliament and the Southern Rhodesian Legislative Assembly was acknowledged in the 1969 Privy Council case of Madzimbamuto v Lardner-Burke, where a breach of the convention would have been considered unconstitutional. ${ }^{75}$ Conventions are the

\footnotetext{
${ }^{69}$ Section 108(6) Government of Wales Act 2006 states that any act of the Welsh Assembly incompatible with EU law or the ECHR, falls outside its competence. Section 24 of the Northern Ireland Act 1998 prohibits any legislation contrary to EU or ECHR law.

${ }^{70}$ s. 2 Scotland Act 2016 adds a further section to Art. 28(7) of the 1998 Scotland Act:

'(8) But it is recognised that the Parliament of the United Kingdom will not normally legislate with regard to devolved matters without the consent of the Scottish Parliament.'

Notably, the second aspect of the Sewel Convention, that relating to changes to devolved institutions' powers, was not so codified.

${ }^{71}$ Or indeed, amendment of the ECA may also require a Legislative Consent Motion.

72 'Nicola Sturgeon: Scotland could refuse Brexit consent', BBC News, 26 June 2016.

${ }^{73}$ Given that the requirement of legislative consent has no statutory basis in Northern Ireland, and is in the process of being given a statutory footing in Wales, but this has not yet been accomplished.

${ }^{74}$ In the 1951 text, Modern Constitutions (Oxford University Press: 1951) 122.

${ }^{75}$ Madzimbamuto v Lardner-Burke [1969] 1 AC 645.
} 
glue that hold the Constitution together. Without them, it may cease to function. So the need to amend devolution legislation renders a UK EU exit constitutionally highly problematic.

If the UK Government continues to assert its view of the constitution, this is another issue that may be raised in the courts, although the courts may declare adherence to parliamentary sovereignty and heed the term 'normally' in the Sewel Convention. In such circumstances, deprived of any meaningful engagement in Art 50 proceedings, and faced with legislative amendments in the absence of legislative consent, it seems devolved governments might lack legal options. Yet such an imposed, one-sided interpretation of the Constitution would renew debates about the nature of the union and could trigger a second Scottish Independence Referendum. In this way, the UK's exit from the European Union could lead to the break up of another union - that of the United Kingdom itself.

\section{Conclusion}

In conclusion, a British exit from the EU risks undermining the very self-determination and national sovereignty that its adherents believe it will bring about. We have seen that claims of national sovereignty are in any case confused and mix up three different concepts of sovereignty. But Brexit also risks shattering the fragile balance and stability of the $\mathrm{UK}^{76}$ by raising the possibility of a further independence referendum in Scotland. Surely such constitutional risks are not to be taken on lightly.

Our Constitution, let alone our constitutional law, does not provide determinate answers to most of the questions posed by Brexit. We might argue that this is unsurprising, that Brexit is an extraordinary event, constitutionally unforeseeable, introducing a potential new revolution into UK law and society. Yet the British Constitution has long been vaunted for its adaptability and its ability cope with new circumstances (the loss of Empire, major world wars, and so on), for its flexibility and enduring nature. However, the challenges of Brexit reveal the Constitution's $21^{\text {st }}$ century weaknesses. An event as momentous as a British withdrawal from the EU requires clear and principled constitutional law as a guide But we do not have that. The British Constitution has become a contested and uncertain object, of sometimes ghostly and shifting form. As a result, we are thrown back onto politics, where the most powerful tend to dominate.

Sionaidh Douglas-Scott

\footnotetext{
${ }^{76}$ Not least by threatening the peace settlement in Northern Ireland.
} 